\title{
Factors influencing positive word-of-mouth intentions of inbound tourists to Japan
}

Masaki Toyama (Tourism Research Department, Japan Travel Bureau Foundation, toyama.masaki.sy@alumni.tsukuba.ac.jp)

\begin{abstract}
This study aims to identify the factors that prompt the intention for positive word-of-mouth regarding travel to Japan. A hypothetical model that incorporates the determinants of positive word-of-mouth was established based on online survey data obtained from people from 12 countries and regions who have visited Japan; and the model was verified through multivariate regression analysis. The results confirmed four factors that positively affect travelers' face-to-face and SNS word-of-mouth intention: customer delight, destination attachment, perceived recognition rate, and photographic evaluation. Furthermore, they suggest that regardless of the type of word-of-mouth communication, the factors that influence positive word-of-mouth intention may be common.
\end{abstract}

\section{Keywords}

inbound tourism, word-of-mouth, destination marketing, social networking service, photogenic

\section{Introduction}

Inviting foreign tourists to Japan (inbound tour-ism) is an important policy issue; and implementing measures to increase foreign tourists' intent to spread positive word-of-mouth regarding their trip to Japan is believed to be an effective means of promoting inbound tourism. Reviews are perceived as objective and credible; and thus have a greater impact on consumers than commercial information [Morrison, 2013]. The more positive reviews spread; the more information is created about Japan as a premiere travel destination. This is because the anticipated rise in positive evaluations is expected to lead to more overseas consumers visiting Japan.

However, in order to actually implement this approach, it is necessary to identify the factors that determine travelers' intentions for positive word-of-mouth communication. Several previous studies have attempted to identify motivations behind word-of-mouth promotion. For example, Litvin et al. [2008] found that these motivations include the expression of emotions and the sharing of the pleasures of travel. Yoo and Gretzel [2011] reported that other types of motivation exist such as those for self-enhancement, to boost self-esteem, and those rooted in the altruistic desire to communicate useful information to others. According to the findings of a consumer behavior study [Saito, 2014], consumers' intentions toward positive word-of-mouth are thought to increase when they expect their motivations to be satisfied.

However, no previous research has offered any suggestions regarding the necessary activities for tourist destinations to effectively satisfy the word-of-mouth motivations. The difficulty in developing relevant initiatives continues to be a recurring issue. Therefore, it is necessary to identify the factors that prompt destination marketing organizations (DMOs) - organizations responsible for destination marketing programs and tourism-related industries - to develop marketing activities, but this has not been sufficiently studied to date.

Based on this information, this study seeks to determine what urges travelers to spread positive word-of-mouth about their trip to Japan. In order to accomplish this, a hypothetical model that incorporates the determinants for intention for positive word-of-mouth communication was established and this model was verified through empirical analysis using survey data.

\section{Hypothetical model}

\subsection{Definition of word-of-mouth and targets for considera-} tion

In line with previous research [Litvin et al., 2008; Westbrook, 1987], this study defines "word-of-mouth" as "communication between consumers about products, services, or businesses that are considered to be independent of commercial impact."

Although face-to-face reviews were primarily used in the past, social networking services (SNS) such as Facebook, Twitter, and Instagram have become more widespread in recent years [Ministry of Internal Affairs and Communications, 2015]; and this resulted in a parallel increase in word-of-mouth communication via SNS. Therefore, two forms of positive word-of-mouth were considered in this study: face-to-face word-of-mouth (hereinafter referred to as "face-to-face") and SNS posts.

\subsection{Establishment of hypothesis}

In this study, "customer delight," "destination attachment," "perceived recognition rate," and "photographic evaluation" were assigned as determinants of intention for positive wordof-mouth communication, in reference to the findings of previous studies. These four factors will be further described in the subsequent sections.

\subsubsection{Customer delight}

Customer delight refers to the surprising, positive emotional response that occurs when a consumer's experience far exceeds expectations [Rust and Oliver, 2000]. As previously mentioned, motivation for word-of-mouth has been said to be able to manifest such emotions [Litvin et al., 2008]. Therefore, the more emotional experiences a consumer has during a trip to Japan, 
the greater the fulfillment of motivation for emotional expression - and the more positive word-of-mouth can be expected.

Based on the above, the following hypotheses were established:

- H1a:

Customer delight has a positive effect on intention for faceto-face word-of-mouth

- H1b:

Customer delight has a positive effect on social media wordof-mouth intentions

Similar to the concept of customer delight, "satisfaction" also refers to emotional reactions that occur when consumers' experiences exceed expectations and affect their intentions for positive word-of-mouth communication [Lee and Back, 2008; Oliver, 2010]. However, when the two are compared, "customer delight" is considered as a stronger emotional reaction than "satisfaction." Therefore, customer delight is included in the hypothesis model instead of the latter in order to emphasize the emotional aspect of the motivations for word-of-mouth.

\subsubsection{Destination attachment}

Destination attachment is a concept that refers to the psychological connection between a particular area and a traveler [Morais and Lin, 2010]. Consumer behavior research has shown that consumers tend to provide word-of-mouth to brands that have strong ties to themselves [Saito, 2014]. Thus, when a destination is regarded as a brand, it is believed that a stronger psychological connection with the destination (i.e., a higher attachment) would lead to a greater intention for positive wordof-mouth communication.

Based on the above, the following hypotheses were established:

- H2a:

Destination attachment has a positive effect on intention for face-to-face word-of-mouth

- H2b:

Destination attachment has a positive effect on intention for SNS word-of-mouth

The above-mentioned knowledge on the "spread of word-ofmouth communication for brand support" suggests that wordof-mouth communication is also motivated by "brand support." By corroborating $\mathrm{H} 2 \mathrm{a}$ and $\mathrm{H} 2 \mathrm{~b}$, it would be possible to highlight the motivations for word-of-mouth support for destinations, which has not yet been done in previous stud-ies.

\subsubsection{Perceived recognition rate}

Perceived recognition rate refers to the consumer's expectations about how well a product or service is perceived [Yamamoto, 2014]. If the perceived recognition rate of word-of-mouth communications is high, then the recipients of word-of-mouth are expected to gain empathy and respect [Yamamoto, 2014] for the communication subject. Based on this point, a higher perceived recognition rate is expected to result in higher intentions for positive word-of-mouth. This is because empathy from the recipients of the reviews leads to satisfaction of the motivation to share the pleasure of travel; and respect can lead to satisfaction of the motivation for self-enhancement.

Therefore, the following hypotheses were established:

- H3a:

Perceived recognition rate has a positive effect on intention for face-to-face word-of-mouth

- H3b:

Perceived recognition rate has a positive effect on intention for SNS word-of-mouth

\subsubsection{Photographic evaluation}

Photographic evaluation refers to the subjective evaluation of photographs taken by consumers while traveling. This is a concept that is unique to this research and is based on the fact that consumers can easily take photos using a smartphone or other mobile devices while traveling.

In this study, a higher photographic evaluation rating was expected to bring about a higher intention for positive wordof-mouth. The presence of highly rated photos not only helps share the enjoyment of travel by showing the recipients of such communication the SNS posts, but also fulfills the motivation for self-enhancement because it allows travelers to showcase themselves more effectively. It is believed to both increase the ease by which useful information can be conveyed to the other party and contribute to the fulfillment of altruistic motivations.

Based on the above, the following hypotheses were established:

\section{- H4a:}

Photographic evaluation has a positive effect on intention for face-to-face word-of-mouth

- H4b:

Photographic evaluation has a positive impact on intention for SNS word-of-mouth

To summarize the discussion thus far, the hypothetical model used in this study is visualized in Figure 1.

\section{Survey methodology}

\subsection{Survey overview}

Data for this study was collected through an online survey which was conducted from June to July 2019. The survey respondents consisted of people from 12 different countries and regions (e.g., South Korea, China, Taiwan, Hong Kong, Thailand, Singapore, Malaysia, Indonesia, the United States, France, the United Kingdom, and Australia) who were 20 to 59 years old and had recently traveled to Japan. The total number of respondents was 2,521. 


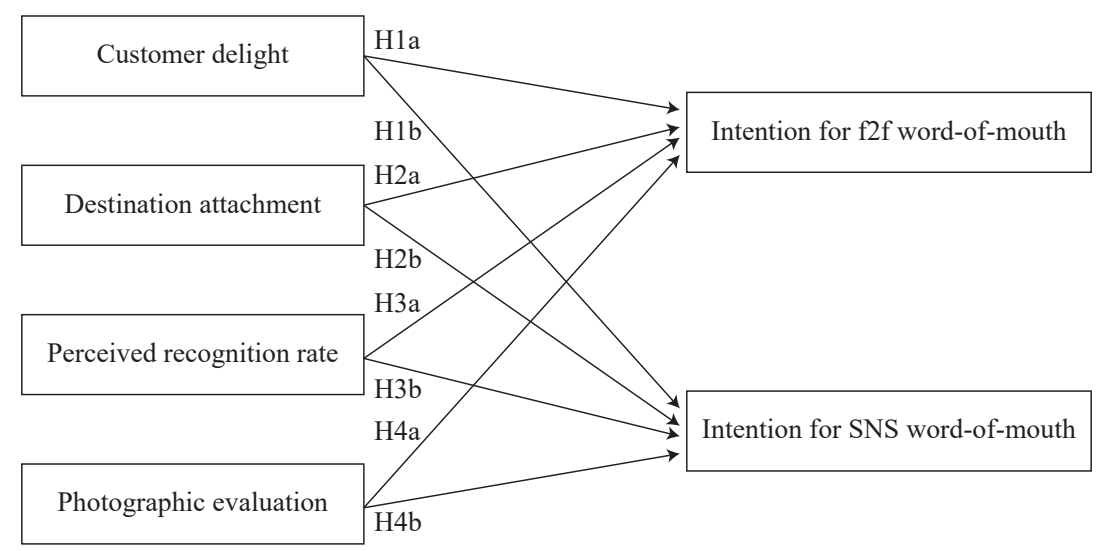

Figure 1: Research model of the study

\subsection{Measurement items}

In terms of customer delight, the frequency of delightful experiences during the most recent trip to Japan was measured using a 5-point likert scale (5: very much to 1 : very less), in reference to Oliver [2010]. Destination attachment was measured by four items on a 7-point likert scale (7: strongly agree to 1: strongly disagree), in reference to previous studies [Chen and Phou, 2013; Prayag and Ryan, 2012]. Based on research done by Yamamoto [2014], the perceived recognition rate was measured by single item on a 7-point likert scale (7: strongly agree to 1: strongly disagree). With respect to photographic evaluation, three items were independently set up and were each measured using a 7-point likert scale (7: strongly agree to 1: strongly disagree). Intention for face-to-face word-of-mouth and SNS word-of-mouth communication were measured by a 7-point likert scale (7: strongly agree to 1 : strongly disagree). Table 1 enumerates the specific measurement items used. Respondents were presented with corresponding translations of the survey into the official languages of each of the 12 countries and regions they came from.

In addition, since the internal consistency (Cronbach's alpha coefficient) of the four items that constitute destination attachment and the three items that constitute photographic evaluation exceeded 0.8 ; the average score of the measurement items for both were used during the subsequent analysis (Table 1).

\section{Results and discussion}

\subsection{Characteristics of respondents}

The characteristics of the survey respondents are summarized in Table 2.

There were slightly more male respondents than female respondents and there was an even age distribution. Majority of respondents came from China, Taiwan, Hong Kong, and Korea.

\subsection{Verification of the hypothetical model}

A multivariate regression analysis was performed to verify the hypothetical model. The analysis was conducted using HAD [Shimizu, 2016]. The hypothesis model components (e.g., customer delight, destination attachment, perceived recognition rate, and photographic evaluation) were used as explanatory variables, whereas the respondent attributes were used as control variables. Specifically, dummy variables were utilized

Table 1: Measurement items used

\begin{tabular}{|c|c|c|}
\hline & Item details & Cronbach's alpha \\
\hline Customer delight & $\begin{array}{l}\text { How often did you feel moved or impressed during your most } \\
\text { recent trip to Japan? }\end{array}$ & - \\
\hline \multirow{4}{*}{ Destination attachment } & I feel a strong attraction towards Japan & \multirow{4}{*}{0.92} \\
\hline & $\begin{array}{l}\text { I can enjoy a more satisfying stay in Japan than in other coun- } \\
\text { tries }\end{array}$ & \\
\hline & I have an attachment to Japan & \\
\hline & Japan is a special place for me & \\
\hline Perceived recognition rate & Japan is well known to my family, friends and acquaintances & - \\
\hline \multirow{3}{*}{ Photographic evaluation } & I was able to take good photos & \multirow{3}{*}{0.88} \\
\hline & I was able to take beautiful photos & \\
\hline & I was able to take fun photos & \\
\hline Intention for $\mathrm{f} 2 \mathrm{f}$ word-of-mouth & I want to recommend others around me to travel to Japan & - \\
\hline Intention for SNS word-of-mouth & $\begin{array}{l}\text { I want to post content recommending travel to Japan on SNS } \\
\text { (Facebook, Instagram, etc.) }\end{array}$ & - \\
\hline
\end{tabular}


Table 2: Characteristics of respondents

\begin{tabular}{|c|c|c|c|}
\hline & & $\mathrm{n}$ & $\%$ \\
\hline \multirow{2}{*}{ Sex } & Male & 1288 & 51.1 \\
\hline & Female & 1233 & 48.9 \\
\hline \multirow{4}{*}{ Age } & $20 \mathrm{~s}$ & 593 & 23.5 \\
\hline & $30 \mathrm{~s}$ & 722 & 28.6 \\
\hline & $40 \mathrm{~s}$ & 619 & 24.6 \\
\hline & $50 \mathrm{~s}$ & 587 & 23.3 \\
\hline \multirow{12}{*}{ Country/region } & China & 355 & 14.1 \\
\hline & Taiwan & 377 & 15.0 \\
\hline & Hong Kong & 406 & 16.1 \\
\hline & South Korea & 355 & 14.1 \\
\hline & Thailand & 218 & 8.6 \\
\hline & Indonesia & 133 & 5.3 \\
\hline & Malaysia & 130 & 5.2 \\
\hline & Singapore & 229 & 9.1 \\
\hline & United Kingdom & 54 & 2.1 \\
\hline & United States & 79 & 3.1 \\
\hline & France & 86 & 3.4 \\
\hline & Australia & 99 & 3.9 \\
\hline
\end{tabular}

to represent gender, age, and country or region. Males took the value of 0 and females, the value of 1 . The 20 s age range was assigned as the reference value instead of the $30 \mathrm{~s}$ to $50 \mathrm{~s}$ age ranges (non-applicable $=0$, applicable $=1$ ). In terms of the respondents' countries or regions, China was set as the reference value (non-applicable $=0$, applicable $=1$ ). On the other hand, intentions for face-to-face word-of-mouth and SNS word-ofmouth were used as objective variables.

Table 3 shows the results of the multivariate regression analysis. When the objective variable was intention for face-to-face word-of-mouth, the adjusted coefficient of determination $\left(R^{2}\right)$ was 0.43 with a level of significance assumed at $5 \%$. When the objective variable was intention for SNS word-of-mouth, $R^{2}$ was 0.36 with a level of significance also assumed at $5 \%$. As shown in above, $R^{2}$ values of two objective variables are relatively low. However, the hypothetical model was judged to have validity, since multiple regression equations were statistically significant.

The variance inflation factor (VIF), an index used for quantifying multicollinearity, determined that multicollinearity did not occur because the VIF for every variable was less than the cutoff value of 10 .

Table 3: Results of multivariate regression analysis

\begin{tabular}{lccc}
\hline & Intention for f2f word-of-mouth & Intention for SNS word-of-mouth & VIF \\
\hline & (Explanatory variables) & & \\
Customer delight & $0.14^{*}$ & $0.06 *$ & 1.55 \\
Destination attachment & $0.2{ }^{*}$ & $0.18^{*}$ & 2.54 \\
Perceived recognition rate & $0.09 *$ & $0.12 *$ & 1.86 \\
Photographic evaluation & $0.32^{*}$ & $0.27 *$ & 1.56 \\
\hline & $($ Control variables $)$ & & 1.02 \\
Gender dummy & 0.00 & -0.01 & 1.60 \\
30s dummy & -0.01 & $-0.04 *$ & 1.60 \\
40s dummy & -0.03 & $-0.11 *$ & 1.61 \\
50s dummy & $-0.07 *$ & $-0.18 *$ & 1.81 \\
Taiwan dummy & $-0.14 *$ & $-0.08 *$ & 1.88 \\
Hong Kong dummy & $-0.21 *$ & $-0.11 *$ & 1.94 \\
South Korea dummy & $-0.07 *$ & $-0.06 *$ & 1.57 \\
Thailand dummy & $-0.03 *$ & $0.05 *$ & 1.34 \\
Indonesia dummy & $-0.05 *$ & -0.02 & 1.33 \\
Malaysia dummy & -0.01 & -0.01 & 1.56 \\
Singapore dummy & $-0.04 *$ & $-0.07 *$ & 1.16 \\
United Kingdom dummy & -0.01 & $-0.06 *$ & 1.20 \\
United States dummy & -0.01 & $-0.05 *$ & 1.23 \\
France dummy & -0.01 & $-0.04 *$ & 1.26 \\
Australia dummy & 0.00 & $0.36 *$ & \\
\hline \multicolumn{1}{c}{$R^{2}$} & $0.43 *$ & & \\
\hline
\end{tabular}

Note: $* p<.05$. 
In Table 3, the numbers in the column of the objective variables represent the standard partial regression coefficients. Given the effect of the control variables, gender did not have a significant effect on face-to-face and SNS word-of-mouth intentions at a $5 \%$ level. The effect of age on face-to-face wordof-mouth intention was significant at a $5 \%$ level for the $50 \mathrm{~s}$ dummy variable. However, the effect of age on SNS word-ofmouth intention was significant at a $5 \%$ level for the $30 \mathrm{~s}, 40 \mathrm{~s}$, and 50s dummy variables. The countries and regions had a significant effect on face-to-face word-of-mouth intention at a $5 \%$ level for the Taiwan, Hong Kong, South Korea, Thailand, Indonesia, and Singapore dummy variables. With respect to SNS word-of-mouth intention, the effect was significant at a 5 $\%$ level for the Taiwan, Hong Kong, South Korea, Thailand, Singapore, the United Kingdom, the United States, France, and Australia dummy variables. The above results suggest that the intentions for face-to-face and SNS word-of-mouth vary depending on certain characteristics of the respondents.

The following describes the verification results of each hypothesis. The effect of cutomer delight on intention for face-toface and SNS word-of-mouth (intention for face-to-face wordof-mouth: $\beta=0.14$; intention for SNS word-of-mouth: $\beta=0.06$ ) was significant at a $5 \%$ level. Therefore, hypotheses H1a and H1b were supported. The effect of destination attachment on intention on face-to-face and SNS word-of-mouth (intention for face-to-face word-of-mouth: $\beta=0.21$; intention for SNS wordof-mouth: $\beta=0.18$ ) was significant at the $5 \%$ level. Therefore, hypotheses $\mathrm{H} 2 \mathrm{a}$ and $\mathrm{H} 2 \mathrm{~b}$ were supported. The effect of the perceived recognition rate on intention for face-to-face and SNS word-of-mouth (intention for face-to-face word-of-mouth: $\beta=0.09$; intention for SNS word-of-mouth: $\beta=0.12$ ) was also significant at a $5 \%$ level. Therefore, hypotheses $\mathrm{H} 3 \mathrm{a}$ and $\mathrm{H} 3 \mathrm{~b}$ were supported. The effect of photographic evaluation on intention for face-to-face and SNS word-of-mouth (intention for face-to-face word-of-mouth: $\beta=0.32$; intention for SNS wordof-mouth: $\beta=0.27$ ) was sig-nificant at a $5 \%$ level. Therefore, hypotheses $\mathrm{H} 4 \mathrm{a}$ and $\mathrm{H} 4 \mathrm{~b}$ were also supported.

In short, all hypotheses were clearly upheld, even with the statistical control of respondent attributes. Moreover, results suggest that the factors that drive positive word-of-mouth communication may be shared regardless of the type of word-of-mouth.

The defining factor with the largest standard partial regression coefficient value among the four was "photographic evaluation" for both face-to-face and SNS word-of-mouth intention (Table 3). Although the development of photogenic spots in tourist attractions has actually been actively pursued in recent years, empirical data confirms that the importance level must be high in order to increase intentions for positive word-ofmouth communication.

\section{Conclusion}

The objective of this study was to determine the factors influencing positive word-of-mouth intentions regarding their travel to Japan. Analysis of data obtained through online sur- veys of people who have visited Japan confirmed the positive causal effect of customer delight, destination attachment, perceived recognition rate, and photographic evaluation on intention for face-to-face and SNS word-of-mouth.

The significance of this study is in its successful identification of several factors that contribute to positive word-ofmouth intentions, with a focus on marketing to DMO and tourism-related industries. The effect of destination attachment on intention for positive word-of-mouth was also confirmed. Furthermore, the results suggest that "support for destinations" could be another potential motivation for positive word-ofmouth that has not yet been explored.

Suggestions in order to promote positive word-of-mouth intention are as follows: First, DMO and tourism-related industries must adopt the experiential marketing strategies [Schmitt, 1999] in order to deliver excitement to customers and leave a lasting impression on them during their stay in Japan. Second, communication through official SNS and promotion of interaction with local residents [Chubchuwong and Speece, 2016] should be actively implemented to maintain visitors' connections in Japan and deepen their bond to the country (i.e., turning them into a fan of Japan). Third, perceived recognition rate must be improved by conducting promotions aimed at raising awareness about Japan in areas where word-of-mouth recipients live. Fourth, the development and advertisement of photogenic spots must be advocated further in order to boost photographic evaluation.

Finally, the limitations and issues concerning this study are as follows: This study revolves around the subject of Japan as a tourist destination. Further studies are needed to determine whether the results of this study are applicable to other destinations. Although this study was primarily concerned with identifying the determinants of intention for word-of-mouth communication, the effects of these determinants on actual word-of-mouth behavior must be further explored in the future. Moreover, in this study, $R^{2}$ values of the hypothetical model were relatively low. The results suggest that other factors influence word-of-mouth intentions, other than factors that examined in this study. Future studies are needed to find possible influential factors of word-of-mouth intentions.

\section{References}

Chen, C. F. and Phou, S. (2013). A closer look at destination: Image, personality, relationship and loyalty. Tourism Management, Vol. 36, 269-278.

Chubchuwong, M. and Speece, M. W. (2016). The "people" aspect of destination attachment in international tourism. Journal of Travel \& Tourism Marketing, Vol. 33, No. 3, 348361.

Lee, J. S. and Back, K. J. (2008). Attendee-based brand equity. Tourism Management, Vol. 29, No. 2, 331-344.

Litvin, S. W., Goldsmith, R. E. and Pan, B. (2008). Electronic word-of-mouth in hospitality and tourism management. Tourism Management, Vol. 29, No. 3, 458-468. 
Ministry of Internal Affairs and Communications (2015). 2015 white paper on information and communications in Japan. https://www.soumu.go.jp/johotsusintokei/whitepaper/ja/ h27/pdf/index.html/.

Morais, D. B. and Lin, C. H. (2010). Why do first-time and repeat visitors patronize a destination? Journal of Travel \& Tourism Marketing, Vol. 27, No. 2, 193-210.

Morrison, A. (2013). Marketing and managing tourism destinations. Routledge.

Oliver, R. L. (2010). Satisfaction: A behavioral perspective on the consumer, 2nd ed. M.E. Sharpe.

Prayag, G. and Ryan, C. (2012). Antecedents of tourists' loyalty to Mauritius: The role and influence of destination image, place attachment, personal involvement, and satisfaction. Journal of Travel Research, Vol. 51, No. 3, 342-356.

Rust, R. T. and Oliver, R. L. (2000). Should we delight the customer? Journal of the Academy of Marketing Science, Vol. 28, No. 1, 86-94.

Saito, K. (2014). WOM generation decision making: The effects of consumer's prediction of market response and brand commitment on generation of WOM about a new brand. Journal of Marketing \& Distribution, Vol. 16, No. 2, 119147.

Schmitt, B. H. (1999). Experiential marketing: How to get customers to sense, feel, think, act, relate to your company and brands. The Free Press.

Shimizu, H. (2016). An introduction to the statistical free software HAD: Suggestions to improve teaching, learning and practice data analysis. Journal of Media, Information and Communication, No.1, 59-73.

Westbrook, R. A. (1987). Product/consumption-based affective responses and post purchase processes. Journal of Marketing Research, Vol. 24 No. 3, 258-270.

Yamamoto, H. (2014). Key person marketing. Toyo Keizai.

Yoo, K. H. and Gretzel, U. (2011). Influence of personality on travel-related consumer-generated media creation. Computers in Human Behavior, Vol. 27, No. 2, 609-621.

(Received January 24, 2020; accepted February 22, 2020) 